\title{
Table of legislation and statutory instruments
}

\section{EUROPEAN UNION}

Directive 2006/49/EC of 14 June 2006 on the Capital Adequacy of Investment Firms and Credit Institutions [2006] OJ L177/201 (Capital Requirement Directive) 49.

EU Commission Delegated Regulation (EU) No 448/2012 of 21 March 2012 supplementing Regulation (EC) No 1060/2009 with regard to regulatory technical standards for the presentation of the information that credit rating agencies shall make available in a central repository established by the European Securities and Markets Authority [2012] OJ L140/ 17 , 146.

EU Commission Delegated Regulation (EU) No 449/2012 of 21 March 2012 supplementing Regulation (EC) No 1060/2009 with regard to regulatory technical standards on information for registration and certification of credit rating agencies [2012] OJ L140/32, 146.

Regulation (EC) No 1060/2009 of 16

September 2009 on credit rating agencies [2009] OJ L302/1 (CRA Regulation), ......4, 72-75, 93, 144, 146-148, 150-151.

Regulation (EU) No 513/2011 of 11 May 2011 amending Regulation
(EC) No 1060/2009 on credit rating agencies [1011] OJ L145/30 (CRA II Regulation), 73,151 .

\section{FRANCE}

Loi française No 2010-1249 du 22 octobre 2010 de régulation bancaire et financière (codified in Code monétaire et financier), $80-82$.

\section{SWITZERLAND}

Federal Ordinance of 29 September 2006 concerning Capital Adequacy and Risk Diversification for Banks and Securities Traders [2006] SR 952.03 (Capital Adequacy Ordinance) $11,235$.

FINMA Circular on Recognition of Rating Agencies for the Assessment of Capital Adequacy Requirements, FINMA-Circ 08/26 (20 November 2008) 47,49 .

\section{UNITED STATES}

Credit Rating Agency Reform Act of 2006, S 3850, 109th Congress (2006) ..29, 68, 166, 198, 208, 214. 
Dodd-Frank Wall Street Reform and Consumer Protection Act of 2010, HR 4173, 111th Congress, 2nd Session (2010) (Dodd-Frank Act) ......4, 9, 11, 61, 64, 69-71, 79, $86,89,93,144-145,148-150$, 155, 197, 225-226, 231, 233.

SEC, Rating Agencies and the Use of Credit Ratings under the Federal Securities Laws, 68 Fed Reg 35,258 (June 12, 2003) 23.

- Oversight of Credit Rating Agencies Registered as Nationally Recognized Statistical Rating Organizations, 72 Fed Reg 33,564 (June 18, 2007) 69.

-Amendments to Rules for Nationally Recognized Statistical Rating Organizations, 74 Fed Reg 6,456 (February 9, 2009) 69 .

- References to Ratings of Nationally Recognized Statistical Rating Organizations, 74 Fed Reg 52,358 (October 9, 2009) ..60.
-Amendments to Rules for Nationally Recognized Statistical Rating Organizations, 74 Fed Reg 63,832 (December 4, 2009) 69. - Release No 68703, Order Making Findings and Imposing Remedial Sanctions and Cease-and-Desist Orders Pursuant to Sections $15 \mathrm{E}(\mathrm{d})$ and $21 \mathrm{C}$ of the Securities Exchange Act of 1934 against Egan-Jones Ratings Company and Sean Egan (January 22, 2013) $150-151$.

Securities Act of 1933, 15 USC $§ 77$ a et seq (as amended through PL 112-106, approved April 5, 2012) .78

Securities Exchange Act of 1934, 15 USC $\S 78$ a et seq (as amended through PL 112-158, approved August 10, 2012) 71,145 , 147-150. 
Aline Darbellay - 9780857939364 Downloaded from PubFactory at 04/26/2023 10:16:37AM via free access 